\title{
PHYSICAL CULTURE - A FRAMEWORK FOR THE MEDIA CLARIFICATION OF MAN'S CULTURAL BEING
}

\author{
Nenad Živanović \\ University of Nis, Faculty of Sport and Physical Education, Serbia
}

\begin{abstract}
Culture, and its related syntagm of physical culture, especially in its most narrow of meanings which refers to spiritual creation, is the foundation of every nation. As a result the term physical culture, which we have for a long time now wanted to unburden ourselves of and leave it in our past, should be rehabilitated, like our colleagues from the Scandinavian countries have done, and it should be given back its (necessary) cultural dimension. Since, as we ourselves know, in the very focus of our profession, physical culture, we find man who is his own biggest mystery. And this man accepts physical movement - exercise, like nourishing food, necessary not only for his body but for his soul. Precisely in that, in this emergence of physical exercise from man's body do we find the entire phenomenology of physical culture. Man experiences "thirst" for various types of satisfaction of his own cultural needs. And just like he has the need to read a good book, hear a good piece of music, look at a beautiful picture, ... he also has the need to add to physical exercise, in a dietary or agonistic sense, everything that has already been mentioned. These expectations of a man desiring spiritual and physical food must be satisfied. The printed and electronic media are a good opportunity to meet this need. After all, these media are at every moment available to man who has increasingly less free time. This is the opportunity to "ad hoc" inform man and encourage him to turn to this aspect of his cultural needs - physical culture.
\end{abstract}

Key words: MAN'S CULTURAL BEING/ PHYSICAL CULTURE / MEDIA

\section{INTRODUCTION}

Culture - as our mirror, in which we can see, if we want to, all that we have endured and all of our ups and downs, just like our conscience has been imprinted into our being by the seal of our elders like our first gospel - it is the foundation of our existence. It is the foundation into which the written word has been embedded, like the cornerstone of our civilization.

It is true, in the beginning there was the Word, Logos. And that Word was God's which he spread everywhere and built into everything visible and invisible. Thanks to that, we have grown from that Word, become a people with our own words and alphabet, this civilizational watershed in the history of human kind. They, this Word and our words, are (also) the foundation of our people.

If we were to look at it from an Orthodox point of view, the forefather of the Nemanjic dynasty of Serbia, Stefan Nemanja, who was later St. Simeon, told everyone who looked around more and admired everyone else's home than their own:

"If you take another's word, know that you have not won it, you have subjugated yourself. It is better to lose the biggest and most fortified city in your country than even the smallest and least known word of your language. Know that the extent to which your enemy has won and conquered you is the number of words of your language he has destroyed and introduced his own in their stead."

Like in the past, today as well, in the second decade of the $21^{\text {st }}$ century, we should listen for the echo of these words and remind ourselves what the Word means, and what our words mean.

Culture as a word and its syntagmatic derivation physical culture, especially in its more narrow sense which refers to spiritual creation, is the foundation of every nation. This is why the term physical culture which we have tried for so long to rid ourselves of and leave behind us in the past should be rehabilitated, as 
our colleagues in Scandinavian countries have done, and once again be reinstated (as a much needed) cultural dimension. Since, as we know, at the heart of our profession of physical culture we find man - his own biggest mystery. And this man accepts physical movement - exercise as nourishment, not only for his body, but for his soul. And precisely there, in this emergence of physical exercise from the body of man, lies all the phenomenology of physical culture.

Let us, after all, remember the words of Milivoje Matić, spoken and recorded a long time ago:

"In the beginning there was movement and it remained... primarily... as exercise" (Matić, M. 1978).

And truly, the ever-increasing technological development, through an excellently designed marketing of hedonism, caters to man's weakness which emerges from a sedentary culture, confirms these words. This conclusion is not just a mere pun, an afterthought, it is in fact our reality permeated with man's physical inactivity. And the increasingly more pronounced (not only?) physical inactivity must lead to: either man's transformation when he will no longer be able to even walk, or to his "awakening" and gaining insight into the necessity of physical movement - exercise.

And that is how we come to the phenomenological breadth of physical culture. Since, as a phenomenon, uniting phenomenologically relevant terms: physical education, sport and physical recreation, it offers answers to many important questions. And to one of these questions, in short: what is the goal of all this physical exercise?, it offers a brief response - that we could remain humans even in our duality, which through the act of baptism is expanded into a trinity, that we equally care both for our body and for our soul. Which is why physical exercise which stems from man, and returns to him, is that deciding factor which enables us to speak of physical culture as a phenomenon.

The general image of man's inactivity, not only physical but also intellectual, even though projected by those who manage this world order still can and must change. Which is why we single out physical culture and its phenomenological breadth. Using all these phenomenological possibilities, man can significantly change his inactive reality. Tethered by the inertia of the social reality programmed to offer man a sense of satisfaction in his intellectual and physical inactivity, it is difficult for man to recognize what is useful. And without outside help it is very difficult for him to change the state he finds himself in.
The media, both printed and electronic, hold an increasingly significant place in the altered awareness of individuals, groups of individuals, as well as nations as a whole. They, using academic patterns of writing, ${ }^{1}$ are an important lever in the formation of a new perspective on the position of an individual in society.

This opportunity should be taken advantage of even through the media, primarily through the written word, since it becomes permanently available to everyone and anyone, to fight for a change in our physical and intellectual inactivity. This is both our duty and our commitment.

\section{PHYSICAL CULTURE AND MEDIA}

Irrespective of how we define physical culture, it always emerges from culture and returns to its fold. At the same time, it removes from the framework of culture what it needs to perform its mission in the time and space which have been assigned to it, but on its return to the fold of culture it always brings with it a pebble which it builds into the mosaic of its being. ${ }^{2}$ This seemingly metaphysical conclusion is actually a normal course of physical culture in the given social circumstances.

Just like culture is the mirror of a nation, with many different stamps of a particular time, so is physical culture. It too is a mirror and stamp of a time and a people. The forms of physical exercise, dietary and agonistic in character, viewed in various periods of time and the social circumstances characteristic of them, indicate that they have changed over time. Their goals changed and were in accordance with the requirements of individual epochs, so that we today can recognize five theories of the development of physical culture, that is, physical education and sport (Živanović, N. 2015).

1 The media use academic patterns of writing to promote an idea: the introduction, body and conclusion. These simple rules, whose values we have gotten know through the 1990s when the preparations to break up the Serbian state were well under way, and the bombing of the country as well, in addition to these guidelines, refer to each individua text as well. Quite often, photography is a powerful tool which through its visual nature promotes an idea - general and/or individual. Due to its value, photography has gradually taken on a leading role in the media.

2 Recently, the Anthology of contemporary Serbian prose on sport by the authors Saša Hadži Tančić and Jugoslav Hadži Tančić has been published. In it we find some of the most beautiful stories of our fiction writers, starting from Ivo Andrić, who found sport to be an inspiration for their writing. 
These five theories are actually five of its mirrors and five stamps of the time which we received as a gift from these epochs. These are the values of our profession which encourage the constant work of those who believe that man is important, as a personality and not an individual, and physical movement -exercise.

And just like man experiences a "thirst" for various types of culture and has a need to read a good book, hear a nice piece of music, see a beautiful painting, ... he also has the need to add physical exercise, in a dietary and agonistic sense, to everything previously mentioned. And if all of this moves him to help himself to the splendor of the rich cultural feast and create his own involvement in physical culture, then it is a sign that all of this was done for the benefit of the human being himself. And that he, this man - personality, unique and singular, will select nourishment which his body needs, as does his soul. This is an important step towards the dissolution of the inert state of inactivity of man's body and his intellect.

And it is precisely this awakening and the severing of this thread of that hedonistic trap which is the cause of his physical and intellectual inactivity that is the challenge facing every physical education professional. These experts also need to be personalities which have not only knowledge but the means to transfer that knowledge. And precisely in that knowledge of how to pass knowledge on, personality gets its own value since, unlike the individual, that small atomized individual, he sees further and sees more; sees that longing of man and his desire to break the chains which his physical and intellectual inactivity is bound by, sees that he cannot succeed in this intent alone - and jumps to his aid.

This help from the experts is not only equal to a lighthouse - which lights the way to those who need it - but also shows that without personality there is no progress, even though many have tried during the course of history (and not just history) to expel personalities who have left a mark in time and space and through its objectivization show that there are objective processes which people adapt to, and that some of them have even proclaimed the very end of history, marking the idea of the fossilization of existing relations in the world.

Fortunately for all of us, this world, and in it culture and our physical culture, still cannot do without man - a personality. This is pointed out by the times and the people living in these times. They are the décor of every culture, and our physical culture as well. And the volatile and turbulent social changes, on the global and local level, only confirm the conclusion that man in each attempt at the creation of social reality is an important and irreplaceable factor. Even the upcoming heralded cyberization of man, we hope, will not succeed.

The desire that man displays to reduce and completely sever all ties with his physical and intellectual inactivity is a good signal for those who are ready to help. Even this "thirst" which his being feels for cultural values, like the values of physical culture, should be reduced by the spreading of a wealthy cultural feast. And man will, based on all his fine cultural feelings, select from that feast what suits and benefits him.

The media today are an important leverage which can move a man to action so that he could completely forget about his physical and intellectual inactivity and return to his own being. They are an opportunity to use fine texts, as well as beautiful photographs, to begin with the changes to man's awareness and his turn towards cultural values which are needed both by his soul, and by his body. And that should be used, for the benefit of all of us.

\section{A framework for media clarification of physical culture}

The media, not without reason, carry the epithet of a force the seventh force to be exact. And we can see this force all around us. With the power to directly, but also indirectly, influence the changes in the awareness of individuals, but also of nations, it creates social reality. It was not by accident that the conclusion what was not in the media actually never even happened emerged.

Of course, this literary device which has been known for quite some time, and which at the beginning was merely a joke, today represents a harsh reality. And this reality indicates that even information of the greatest importance in the media only "lives" for a few days. This is, quite certainly, a consequence of several reasons, which might be boiled down to two of the most important ones: (a) the ever more rapid internet enables the quicker transfer of information and (b) it is necessary for the users of this information (the readers) not to think about this information. This is perhaps the most important part of the story of the strategist who is in possession of this information - in small doses, as if it were a cure, it should perform previously set tasks. 
This rapid succession of information is characteristic for these areas of social life which the media follow. From politics and economy, to entertainment and sport they abide by the same rules. Academic patterns: introduction, body, conclusion, especially when something needs to start living: an idea, a program, a decision. Certainly, this type of approach to the media creating social reality also has positive aspects - when they fight for the values which are in favor of the well-being of man, as well as the nation as a whole. And this should be used, this positive side of the media.

The media which promote shorter (or longer) analytical texts are very suitable for professionals in the field of physical culture. And they should be used to represent physical culture in all its cultural breadth. By means of texts which are based on its philosophy at whose center is man, a secret even unto himself and physical exercise, as the nourishing food for his body and to his soul it is possible to gradually spread the idea of the benefits of physical exercise and physical movement. That is the basic and most important idea. But along with it, texts should be focused on the fields of physical culture: physical education, sport and physical recreation. Relying on their philosophy it is possible to represent the cultural wealth of these fields, with all their advantages and shortcomings. And in all of that one should see man.

Man, of course, feels and has a need for the satisfaction of that aspect of his personality which he refers to as his being spiritual. Beautiful texts, often at the level of short essays, can satisfy even that frail side of his personality and to lift him to the level when he begins to think, not only about who he is and what he is but to also think about how and which road to take. In that line of thinking, which is actually a privilege in this fast-paced world in which sedentary culture is increasingly more dominant, man should be motivated to think about physical culture as something that he needs and lacks. And a fine word, written or spoken, which brings back beautiful memories, just like a photograph, helps to refresh man's knowledge about something interesting and current, and all this together might encourage to satisfy both his physical and spiritual need for physical movement - exercise.

In that attempt to help man in his search for himself lies the beauty of our physical culture and of each individual effort. The reward for effort and for each of its followers is the smile on the face of the people around them, healthy and happy adults and children.
The reward is the feeling that we have done something good, within our profession, for the well-being of the people around us. That this is the case has been proven by the epochs which are behind us and the people, experts, which adorned them.

A reward, truly great and worthy!

\section{Media rules}

A text prepared for the media (printed and electronic) must respect its rules. The most important among them, certainly, are the rules which refer to the extent of the text and it current status.

The extent of the text, depending on the media and the column for which it is being written is determined beforehand. This is especially relevant for the printed media and is measured usually by the number of "characters", and less frequently by the number of words or the number of rows. Modern technology, with the constant pressure and insistence on the speed and rationalization of the employed, turns editors of certain columns into technical advisors. They have at their disposal several broken (modified) models of their pages, and their task is also to adapt the texts they select into previously formatted windows (spaces). In the given space we must include each text. And that is why we must bear this in mind while writing.

The current nature of the text is one of the more important assumptions for publication in the media. The more dense sequence of current events today, both in the country and in the world at large, must be followed by the media. What depends on this is the size of their readership, the number of visits to their websites, and all this leads to the number and quality (expressed financially) of advertisements and advertisement messages which are being published. Even in this game with time and the current status of information we must find texts from within the domain our profession. They must be up-to-date to fit into the sequence of events which these media follow.

In addition to these two of the most important media rules, a few other things need to be taken into consideration:

A text based on correct facts, which are made public, since there remains a historical trace available in the media archives, but also in the archives of public samples of these media. ${ }^{3}$ As a result it is necessary to

3 We are witnesses of half-truths and falsehoods which are being promoted not only in the world media, but the local media as well. With their publication, at the expense of someone or of some idea (material in most cases), the formation of 
check every piece of data which is being used, especially if a person writes for a particular media type over longer periods of time, because of the confidence the readers have in the published texts of a single author. This confidence is difficult to achieve, as we know, and is very easy to lose. As a result, but also for the benefit of our profession, the texts must be based on verified data.

The language and style of writing, of course depend on the author himself. But, it is necessary to bear in mind the overwhelming number of those following this medium (or media). And depending on the population group the author is addressing, it is necessary for him to use the language (terminology) and the style of writing suited to that particular group. And if it is impossible to omit any sample of professional jargon, understandable to the professionals involved in that particular field, then it is desirable to use an explanation of this term in brackets. After all, the purpose of the texts in the media is not to "impress" the reader with the language they do not understand, but to inform them of something.

The educational aspect, or the opportunity to expand the reader's knowledge should be nurtured in each text. The fast pace of our time and of ourselves in that time leads not only to the expansion of fast food but also of information in the form of quick reminders and knowledge. That is why in short texts, of approximately 60 lines, finely molded, the reader should find out something new or to remind himself of what he has forgotten. ${ }^{4}$ And when he comes across something interesting in the text, if he also writes this information down so as not to forget it or to use it in his own writing, then that is a sign of a very good text. And of course, efforts should be made to have as many of these texts as possible which the readers will read with a pencil in their hands.

These few rules that we have mentioned are merely reference points which should be used when one writes for the media. And each author and each medium in particular will find the best formula to ap-

opinion and a change in awareness is being influenced. In the 1990s, and even today, we are exposed to such efforts, all in the desire to present us as the bad guys or the bad nation.

4 Milan Vujaklija, at the end of his Preface to the second edition of his Lexicon included a quote in Latin: Indocti discant et ament meminisse periti (Let the unlearned learn and the learned take pleasure in refreshing their memories.). These words were not written in vain, and are especially current at a time when we are struggling for education during the course of our entire lives. proach the reader. It is important to encourage the desire among the readers to turn to the values of physical culture and their physical movement - exercise - like a nourishing food for their physical, but also their spiritual being. Everything else will come in its own time - the fine texts, and the beautiful photographs, and the fine walks, and the basketball shots, maybe made in the company of one's own grandson. This is truly useful and nice.

\section{CONCLUSION}

Rapid technological development, urbanization with the tendency towards megalopolises and new smart cities, limited living and working space, are only some of the characteristics of the world and time we live in. And it is quite understandable that even the cultural needs of man would be adapted to the given conditions.

But even in addition to this cruel reality, man in his being has, and attempts to maintain, his roots preserved in his memory. This memory, which is written in the genetic code which he was handed down from his ancestors, helps him to survive (even) in this day and age. And this memory is actually hope that, as the poet would say, not everything is lost when everything is (R. P. Nogo). That is why there is hope that culture, and physical culture that has emerged from it, will help man to remain a personality - unique and singular, which will enable him to preserve the duality of body and soul, through baptism brought to the level of the trinity, even in the given social circumstances.

The media, both the printed and electronic, can be of great use in this respect. And that should be used in the careful approach to each of them. Through different forms of texts we can satisfy the needs of all their readers for the fine word, photograph, information, piece of advice. And all with the aim of creating in their minds the thought of beauty and the necessity of physical movement - exercise. This is the exalted mission of every professional in the field of physical culture which also leaves (even) our seal in the time and space we live in. 


\title{
REFERENCES
}

1. Vujaklija, M. (1966). Leksikon stranih reči i izraza. [Lexicon of foreign words and expressions, In Serbian]. Prosveta, Beograd.

2. Živanović, N. (2015). On Physical Education and Sport, in: History of Physical Education in Europe, book I. Faculty of Sport and Physical Education and FIEP Europe - History of Physical Education and Sport Section, Leposavić. pp. $8-23$.
3. Matić, M. (1978). Čas telesnog vežbanja. [A class of physical exercise, In Serbian]. NIPU Savez za fizičku kulturu Jugoslavije, Beograd.

4. Hadži Tančić, S., Hadži Tančić, J. (2017). Antologija savremene srpske proze o sportu. [Anthology of Contemporary Serbian Prose about Sport, In Serbian]. Fakultet za sport i fizičko vaspitanje, Leposavić; FIEP Srbija - Sekcija za istoriju fizičkog vaspitanja i sporta FIEP Evrope; Fakultet sporta i fizičkog vaspitanja, Niš.

\section{KÖRPERKULTUR - RAHMEN FÜR DIE MEDIENBEGRÜNDUNG DES MENSCHLICHEN KULTURWESENS}

\begin{abstract}
Zusammenfassung
Kultur und das aus ihr abgeleitete Sintagma Körperkultur ist, ganz besonders in ihrer engeren Bedeutung, die sich auf geistliches Schöpfertum bezieht, die Grundlage jedes Volkes. Aus diesem Grunde sollten wir den Termin Körperkultur, von dem wir uns so intensiv und lange befreien und ihn der Vergangenheit überlassen möchten, rehabilitieren, so wie es unsere Kollegen in Skandinavien tun, und ihm seine (für uns unabkämmliche) kulturelle Dimension zurückgeben. Wie wir wissen, befindet sich im Mittelpunkt unseres Fachs, der Körperkultur, der Mensch, das höchste Geheimnis, dem der Mensch selbst entgegentritt. Dieser Mensch nimmt körperliche Bewegung - Übung als wohltätige Nahrung, unumgänglich nicht nur für seinen Körper, sondern auch für seine Seele. Gerade darin, in diesem Entspringen der körperlichen Übung aus dem menschlichen Wesen liegt die Phänomenologie der Körperkultur. Der Mensch verspürt „Durst“ nach unterschiedlichen Formen der Befriedigung seiner kultureller Bedürfnisse. Sowie er das Bedürfnis nach einem guten Buch, nach lieblicher Musik, nach einem schönen Bild verspürt ... hat er auch das Bedürfnis, der körperlichen Übung im diätätischen und agonistischen Sinne all das hinzu zu fügen, was wir aufgezählt haben. Diese Erwartungen des Menschen, der nach geistlicher und körperlicher Nahrung dürstet, müssen befriedigt werden. Gedruckte und elektronische Medien sind eine gute Gelegenheit, um auf diese Bedürfnisse zu antworten. Diese Medien sind in jedem Moment zugänglich für alle Menschen, die immer weniger Freizeit haben. Dies ist eine Gelegenheit, sie „im Gehen“ zu informieren und sie dazu zu inspirieren, sich auch dieser Seite ihrer kultureller Bedürfnisse zuzuwenden - der Körperkultur.
\end{abstract}

Schlüsselwörter: DER MENSCH ALS KULTURWESEN / KÖRPERKULTUR / MEDIEN

Received: 01.11.2017

Accepted: 15.11.2017 


\title{
ФИЗИЧКА КУЛТУРА - ОКВИР ЗА МЕДИЈСКО ПОЈАШЫЕЊЕ ЧОВЕКОВОГ КУЛТУРНОГ БИЋА
}

\author{
Ненад Живановић \\ Универзитет у Нишу, Факултет спорта и физичког васпитања
}

\begin{abstract}
Сажетак
Култура, и из ње изведена синтагма физичка кулитура, нарочито у њеном ужем значењу које се односи на духовно стваралаштво, темељ је сваког народа. 3бог тога и термин физичка култура, којег тако силно и дуго желимо да се ослободимо и оставимо га у прошлости, треба да рехабилитујемо, као што то чине наше колеге у скандинавским земљама, и повратимо му (нама неопходну) културолошку димензију. Јер, као што знамо, у средишту наше струке, физичке културе, налази се човек, тиајна највиша и самоме себи. И тај човек телесну кретњу - вежбу прихвата као благодатну храну, неопходну не само његовом телу већ и његовој души. Управо у томе, у том извирању физичке вежбе из бића човековог, лежи сва феноменологија физичке културе. Човек осећа „жећ“ за различитим видовима задовољења својих културолошких потреба. И као што има потребу да прочита неку лепу књигу, чује лепу музику, види лепу слику, ... има и потребу да физичкој вежби, у дијететском или агонистичком смислу, придода све оно што смо набројали. Та очекивања човека жељног духовне и телесне хране треба задовољити. Штампани и електронски медији су добра прилика да се одговори на ову потребу. Јер, ови медији су у сваком тренутку доступни човеку који има све мање слободног времена. А то је прилика да га „У ходу“ информишемо и подстакнемо да се окрене и тој страни својих културолошких потреба - физичкој култури.
\end{abstract}

КљУчне речи: ЧОВЕК КАО КУЛТУРНО БИЋЕ / ФИЗИЧКА КУЛТУРА / МЕДИЈИ

\section{УВОД}

Кулйура - као наше оіллеgало, у коме можемо да видимо, ако желимо, сва наша трајања и све наше успоне и падове, али и као наша савес $\bar{u}$, печатом наших прародитеља утиснута у наше биће као наше прво јеванђеље - темељ је нашега постојања. То је темељ у коме је узидана писана реч, као наш цивилизацијски оквир.

Јесте, на почетку је била Реч, Логос. И та је Реч била у Бога коју је Он разаслао свуда и уградио у све видљиво и невидљиво. Захваљујући томе и ми смо из те Речи израсли, постали народ са својим речима и писмом, том цивилизацијском преломницом у историји људског рода. Оне, та Реч и наше речи, темељ су (и) нашег народа.

Када смо православно прогледали, родоначелник немањићке Србије Стефан Немања, потоњи Св. Симеон, поручио је свима који су више гледали и дивили се туђем дворишту неголи свом:
„Узмеш ли туђу реч, знај да је ниси освојио него си сеље потуђио. Боље ти је изгубити највећи и најтврђи град своје земље него најмању и најнезнатнију реч свога језика. Знај да те је непријатељ онолико освојио и покорио колико ти је речи потро и својих потурио.“

Како некада, тако и сада, у другој десетици 21. века, треба ослушкивати ехо ових речи и подсећати се шта значи Реч и шта значе наше речи.

Кулитура као реч и њена синтагмичка изведеница физичка кулйура, нарочито у њеном ужем значењу које се односи на духовно стваралаштво, темељ је сваког народа. Због тога и термин физичка кулитура, којег тако силно и дуго желимо да се ослободимо и оставимо га у прошлости, треба да рехабилитујемо, као што то чине наше колеге у скандинавским земљама, и повратимо (нама неопходну) њену културолошку димензију. Јер, као што знамо, у средишту наше струке, физичке кул$\bar{m} y p e$, налази се човек - тајна највиша и самоме

166 Кореспонденција са: Ненад Живановић, Универзитет у Нишу, Факултет спорта и физичког васпитања, Чарнојевића 10a, 18000 Ниш, Србија; е-mail: nenad.zivanovic46@gmail.com 
себи. И тај човек телесну кретњу - вежбу прихвата као благодатну храну, неопходну не само његовом телу већ и његовој души. И управо у томе, у том извирању физичке вежбе из бића човековог, лежи сва феноменологија физичке културе.

Сетимо се, уосталом, речи Миливоја Матића давно изговорених и написаних:

„На почетку би кретање и оста ... превасходно ... као вежбање“ (Матић, М. 1978).

И заиста, све бржи технолошки развој, кроз одлично осмишљен маркетинг хедонизма, повлађујући човековој слабости која извире из сеgеће кул$\bar{u} y p e$, потврђује ове речи. Ова констатација није тек узгредна игра речима, већ наша стварност сва саткана од човекове физичке неактивности. И та све израженија (не само?) физичка неактивност мора да доведе: или до човекове трансформације када више неће моћи чак ни да хода, или до његовог „буђења“ и увиђања неопходности телесног кретања - вежбања.

И тако долазим до феноменолошке ширине физичке културе. Јер она као феномен, обједињавајући такође феноменолошки значајне појмове: физичко васпитање, спорт и физичку рекреациjy, пружа одговоре на многа значајна питања. А једно од тих питања, кратко: чему све $\bar{\imath} о$ физичко вежбање?, нуди кратак одговор - да бисмо остали људи и у свом двојству, које крштењем проширујемо у тројство, подједнако бринемо како о свом телу тако и о својој души. Због тога је и физичка $в е ж \delta а$, која извире из човека и њему се враћа, онај пресуђујући чинилац који омогућава да о физичкој култури говоримо као феномену.

Општа слика човекове неактивности, не само физичке већ и интелектуалне, иако је пројектова-

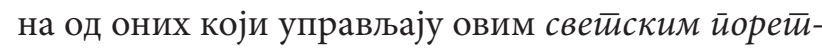
ком, ипак може и мора да се мења. Зато и указујемо на физичку културу и њену феноменолошку ширину. Користећи све њене феноменолошке могућности, човек може значајно да промени своју неактивну стварност. Прикован инерцијом друштвене стварности програмираном да човеку понуди осећај задовољства у својој интелектуалној и физичкој неактивности, тешко му је да препозна оно што је корисно. А ठез помоћи са стране врло тешко може да промени стање у које је доспео.

Медији, како штампани тако и електронски, имају све значајније место у промени свести појединаца, појединих група, као и народа у целини.
Они, користећи школске обрасце за писање, ${ }^{1}$ представљају значајну полугу у формирању новог погледа на место појединца у једном друштву.

Ову прилику треља искористити и преко медија, писаном речју пре свега, јер она остаје трајно доступна свима и свакоме, залагати се за промену наше физичке и интелектуалне неактивности. То је наша обавеза и лепа дужност.

\section{ФИЗИЧКА КУЛТУРА И МЕДИЈИ}

Без обзира на то како дефинишемо физичку културу, она увек извире из културе и враћа се у њено окриље. Притом, износи из окриља културе оно што јој је потребно да би обавила своју мисију у времену и простору који су јој задати, али при повратку у окриље културе увек доноси по који камичак и уграђује га у мозаик њеног бића. ${ }^{2}$ Ова наизглед метафизичка констатација заправо је један нормалан пут физичке културе у датим друштвеним околностима.

И као што је култура огледало једног народа, са много различитих йечайа јеgної времена, тако је и са физичком културом. И она је огледало и печат једног времена и једног народа. Облици физичког вежбања, дијететског и агонистичког карактера, посматрани у различитим временима и њима карактеристичним друштвеним околностима, показују да су се током времена мењали. Њихови циљеви су се мењали и усаглашавали са захтевима појединих епоха, тако да ми данас можемо да препознамо пет теорија развоја физичке културе, односно физичког васпитања и спорта (Живановић, Н. 2015).

Ових пет теорија су заправо пет њених огледала и пет печата времена које смо добили на по-

1 Медији користе школске обрасие йисаюа за пласирање једне идеје: увод, разрада и закључак. Ова једноставна правила, чију смо вредност упознали деведесетих година прошлога века када је вршена припрема за разбијање српске државе и њено бомбардовање, поред тих општих смерница, односе се и на сваки појединачни текст. Врло често, фотографија је моћно средство које својом визуелношћу истиче идеју - општу и(ли) појединачну. Због те њене вредности, фотографија постепено из споредне преузима главну медијску улогу.

2 Недавно је објављена Анииолоіија савремене срӣске йрозе о $c \bar{u} о р \bar{u} y$ аутора Саше Хаџи Танчића и Југослава Хаџи Танчића. У њој су објављене најлепше приче наших књижевника, почевши од Иве Андрића, којима је спорт био повод за писање. 
клон из тих епоха. То су вредности наше струке које подстичу на сталан рад свих оних којима је важан човек, као личност а не индивидуа, и његова телесна кретња - вежба.

И као што човек осећа „жеђ“ за различитим видовима културе и има потребу да прочита неку лепу књигу, чује лепу музику, види лепу слику, ... има и потребу да физичкој вежби, у дијететском или агонистичком смислу, придода све оно што смо набројали. А ако га све то подстакне да се и сам послужи са те богате културолошке трпезе и сам креира своје ангажовање у физичкој култури, онда је то знак да је све ово рађено на корист самом бићу човековом. И да ће он, тај човек - личност, јединствена и непоновљива, бирати храну која је потребна како његовом телу, тако и његовој души. То је значајан корак ка разбијању инертног стања неактивности његовог тела и његовог интелекта.

И управо то буђење и раскидање нити оне хедонистичке замке која је узрок његове физичке и интелектуалне неактивности изазов је сваког стручњака у физичкој култури. И ти стручњаци морају да буду личности које красе не само знање које поседују већ и знање како то знање пренети. И уйраво у йом знану како знане gатичи, личност добија своју вредност јер, за разлику од индивидуе, тог сићушног атомизираног појединца, види и даље и више; види тај вапај и жељу човека да раскине ланце којима је увезана његова физичка и интелектуална неактивност, види да не може сам да успе у тој својој намери - и прискаче у помоћ.

Та помоћ стручњака не само да је равна светионику - који осветљава пут онима којима је та светлост потребна, - већ и показује да без личности нема напретка, иако су многи покушавали да из историје (и не само ње) избаце личности које су оставиле траг у времену и простору и њеном објективизацијом покажу да постоје објективни процеси којима се људи прилагођавају, а неки од њих чак су објављивали и сам крај историје, оцртавајући идеју фиксације постојећих односа у свету.

На срећу свих нас, ипак овај свет, а у њему култура и наша физичка култура, не могу без човека - личности. То показују времена и људи у тим временима. Они су украс сваке културе и, такође, наше физичке културе. А бурне и узбуркане друштвене промене, на светском као и локалном нивоу, само потврђују констатацију да је човек у сваком креирању друштвене стварности важан и ничим заменљив фактор. Чак и најава предстојеће киборгизације човека, надамо се, неће успети.

Жеља коју човек показује да смањи и потпуно прекине са својом физичком и интелектуалном неактивношћу добар је сигнал за оне који су спремни да помогну. И ту „жеђ“ коју осећа његово биће за културним вредностима, као и вредностима физичке културе, треба смањити ширењем богате културолошке трпезе. А он ће, све према својим тананим културолошким осећајима, бирати са те трпезе оно што му прија и што му годи.

Медији су данас моћна полуга којом је могуће покренути човека на акцију како би се вратио себи и свом бићу. Они су и прилика да се лепим текстовима, као и лепим фотографијама, почне са променом човекове свести и његовом окретању ка културолошким вредностима које су потребне како његовој души, тако исто и његовом телу. И то треба користити, на добробит свих нас.

\section{Оквир за медијско појашњење физичке културе}

Медији, не без разлога, носе епитет силе, и то сеgме силе. А ту силу можемо да видимо свуда око нас. Уз моћ да директно, али и индиректно, утиче на промену свести појединаца, али и народа, она креира и друштвену стварност. Није тек тако изникла констатација да оно шӣо није било у меgијима, заирраво се није ни gоїодило.

Наравно, ова одавно позната изрека, која је у почетку била на нивоу шале, данас представља сурову реалност. А та реалност показује да и информације од највеће важности у медијима „живе“ тек неколико дана. То је, свакако, последица неколико разлога, који могу да се сведу на два најважнија: (а) све бољи интернет омогућава

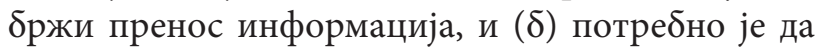
корисници тих информација (читаоци) не размишљају о тим информацијама. Ово је заправо најважнији део приче стратега који поседују те информације - дозирано, као да су лек, оне треба да обаве унапред одређене задатке.

Овакав брзи след информација карактеристичан је за све области друштвеног живота које медији прате. Од политике и економије, па до забаве и спорта, делује се по истим правилима. И то школским обрасцима: yвоg, разраgа, закльучак, нарочито када нешто треба да заживи: идеја, програм, одлука. Свакако, овакав приступ медија 
креирању друштвене стварности има и позитивне аспекте - када се залажу за вредности које су окренуте добробити човека, као и народа у целини. И то треба искористити, ту позитивну страну медија.

Медији који негују кратке (или дуже) аналитичке текстове веома су погодни за стручњаке из области физичке културе. И треба их искористити за представљање физичке културе у свој својој културолошкој ширини. Текстовима који се базирају на њеној философији у чијем је средишту човек, йајна и самоме себи, и физичка вежба, као

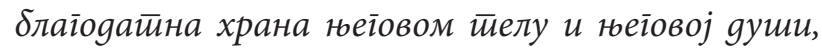
могуће је постепено ширити идеју о благодети физичке вежбе и физичког вежбања. То је основна и најважнија идеја. Али, уз њу треба текстове усмерити и на подручја физичке културе: $б u$ зичко васиичйање, сйорй и бизичку рекреацију. Ослањајући се на њихову философију могуће је представити културолошко богатство самих тих подручја, са свим њиховим узлетима и падовима. И у свему томе треба да се види човек.

Човек, наравно, осећа и има потребу и за задовољењем оне стране своје личности коју врло често називамо духовном. Лепим текстовима, често на нивоу кратких есеја, може да се задовољи и та танана страна његове личности и да га уздигне до нивоа када почиње да мисли, не само ко је и шй je, већ и да размишља како и којим йуйем gаље. У том размишљању, које је заиста привилегија у овом убрзаном свету у коме је „лежећа култура“ све доминантнија, треба подстакнути и мисли о физичкој култури као нечему што је човеку потребно и што му недостаје. И лепа реч, писана или изговорена, која буди лепе успомене, баш као и фотографија, помажу да се освежи знање о нечему интересантном и актуелном, а све то заједно може да га подстакне да и своју телесну и духовну потребу за телесном кретњом - вежбом, задовољи.

У том настојању да се човеку помогне у трагању за самим собом лежи лепота наше физичке културе и сваког појединачног труда. Награда за труд сваког њеног посленика је осмех на лицу људи око њих, здрава и срећна деца и одрасли. Награда је и осећај да смо нешто добро урадили, унутар струке, а на добробит људи око нас. Да је тако, то показују епохе које су иза нас и људи, стручњаци, који су их красили.

Награда, заиста велика и вредна!

\section{Медијска правила}

Текст припреман за медије (штампане и електронске) мора да поштује њихова правила. Најважнија међу њима су, свакако, правила која се од-

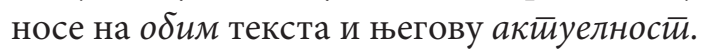

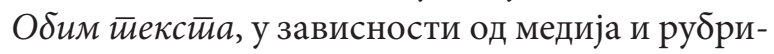
ке за коју се пише, унапред је одређен. Ово нарочито важи за штампане медије и мери се најчешће бројем „карактера“, а ређе бројем речи или бројем редова. Савремена технологија, уз стални притисак и инсистирање на брзини и рационализацији броја запослених, уреднике појединих рубрика претвара и у техничке уреднике. Имају на располагању неколико преломљених (обликованих) модела својих страница, и њихов је задатак да текстове које изаберу уклопе у већ форматиране прозоре (просторе). У (за)дати простор мора да се уклопи сваки текст. И зато о томе треба водити рачуна већ приликом писања.

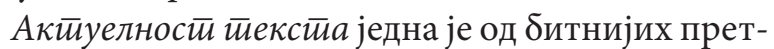
поставки за објављивање у медијима. Све гушћи низ актуелних дешавања, како у земљи тако и у свету, медији морају да прате. Од тога зависи њихова читаност, посећеност њихових сајтова, а то све условљава број и квалитет (финансијски исказан) реклама и рекламних порука које објављују. И у тој иіри са временом и акйуелношћу морају да се нађу и текстови из домена наше струке. Њихова актуелност мора да се уклопи у след догађаја које ти медији прате.

Поред ова два најважнија медијска правила, за добар текст потребно је имати у виду још нека:

Тексй заснован на йачним чиюеницама, које се износе, остаје историјски траг доступан у архивама медија, али и архивама народних библиотека у којима се чувају штампани примерци тих медија. ${ }^{3}$ Због тога је неопходно проверити сваки податак који се користи, нарочито ако се у дужем континуитету пише за одређени медиј, због поверења читалаца у објављене текстове једног аутора. То поверење се тешко стиче, а као што знамо, врло лако губи. Због тога, али и због добробити

3 Сведоци смо полуистина и неистина које се износе не само у светским медијима, већ и локалним. Њиховим изношењем, за рачун некога или неке идеје (материјалне у већини случајева), утиче се на креирање мишљења и промену свести. Деведесетих година, па и сада, изложени смо таквим настојањима, а све у жељи да се сами прогласимо лошим момиима и неваљалим народом. 
наше струке, текстови морају да буду засновани на провереним подацима.

Језик и сииил йисань, наравно, зависе од самог аутора. Али, потребно је имати у виду преовлађујући број оних који прате тај медиј (или медије). И у зависности којој популационој групи се аутор обраћа, потребно је и да свој језик (терминологију) који користи и стил писања прилагоди тој групи. А ако се у току писања не може избећи неки стручан термин, разумљив професионалцима те струке, онда је пожељно у загради дати објашњење тог стручног термина. Јер сврха текстова у медијима није да „импресионира“ читаоца језиком који он не разуме, већ да га информише о нечему.

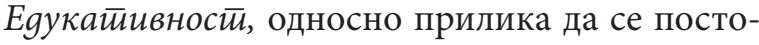
јеће знање читаоца прошири, треба неговати у сваком тексту. Ужурбаност нашег времена и нас у том времену не доводи само до експанзије $\delta p з е$

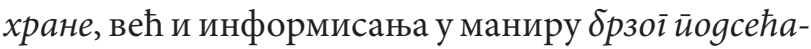
ға и сазнавана. Зато у кратком тексту, на пример од 60 редова, лепо обликованом, читалац треба нешто ново да сазна или да се подсети онога што је заборавио. ${ }^{4}$ А када наиђе на нешто интересантно у тексту, и то запише како ту информацију не би заборавио или је искористио за неко своје писање, онда је то ознака за веома добар текст. И наравно, треба се трудити да буде што више таквих текстова који ће се чийатии са оловком у руци.

Ових неколико правила које смо поменули само су оријентири које треба користити када се пише за медије. А сваки аутор и сваки медиј понаособ наћи ће најбољу формулу за приступ читаоцу. Важно је да се тим текстом подстакне жеља код читалаца да се окрену вредностима физичке културе и своју телесну кретњу - вежбу осете као благодатну храну свог телесног, али и духовног бића. Све остало ће доћи само по себи - и леп текст, и лепа фотографија, и лепа шетња, и лепо убацивање лопте у кош, можда у друштву унука. Заиста корисно и лепо.

4 Милан Вујаклија је на крају Предговора за друго издање свог Лексикона стираних речи и израза ставио једну латинску мисао: Indocti discant et ament meminisse periti (Они који не знају, нека уче, а који знају, нека налазе задовољство у томе да се подсећају). Нису ове речи узалуд написане, а нарочито су актуелне у времену када се боримо за образовање током целог живота.

\section{ЗАКЉУЧАК}

Брз технолошки развој, урбанизација са тенденцијом ка мегаполисима и новим йамейним градовима, органичен живорни и радни простор, само су неке од карактеристика света и времена у коме живимо. И сасвим је разумљиво да се и културилошке потребе човека прилагођавају датим условима.

Али и поред ове сурове реалности, човек у своме бићу има, и труди се да очува, своје корене сачуване у свом сећању. То сећање, које је записано у генетском коду који је добио од прародитеља, помаже му да опстане (и) у овом времену. И то сећање је заправо нада да, како би песник рекао, није све ирройало каg ирройало све је (Р. П. Ного). Зато и нада да ће култура, и из ње изникла физичка култура, помоћи човеку да остане личност - јединствена и непоновљива, која ће моћи своје двојство тела и душе, крштењем уздигнуто на ниво тројства, да очува и у (за)датим друштвеним околностима.

Медији, подједнако штампани као и електронски, у томе могу бити од велике помоћи. И то треба искористити пажљивим приступом сваком од њих. Различитим формама текстова могу се задовољити потребе свијих читалаца за лепом речју, фотографијом, информацијом, саветом. И све то у смеру да се у њиховим мислима појави и мисао о лепоти и неопходности телесне кретње - вежбе. То је за све стручњаке из области физичке културе узвишена мисија која оставља (и) наш печат у времену и простору у коме живимо. 


\title{
ЛИТЕРАТУРА
}

1. Вујаклија, М. (1966). Лексикон ситраних речи и израза. Просвета, Београд.

2. Živanović, N. (2015). On Physical Education and Sport, in: History of Physical Education in Europe, book I. Faculty of Sport and Physical Education and FIEP Europe - History of Physical Education and Sport Section, Leposavić,. pp. 8 - 23 .
3. Матић, М. (1978). Час йелесноі вежбања. НИПУ Савез за физичку културу Југославије, Београд.

4. Хаџи Танчић, С., Хаџи Танчић, J. (2017). Ан-

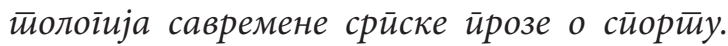
Факултет за спорт и физичко васпитање, Лепосавић; ФИЕП Србија - Секција за историју физичког васпитања и спорта ФИЕП Европе; Факултет спорта и физичког васпитања, Ниш.

\section{KÖRPERKULTUR - RAHMEN FÜR DIE MEDIENBEGRÜNDUNG DES MENSCHLICHEN KULTURWESENS}

\begin{abstract}
Zusammenfassung
Kultur und das aus ihr abgeleitete Sintagma Körperkultur ist, ganz besonders in ihrer engeren Bedeutung, die sich auf geistliches Schöpfertum bezieht, die Grundlage jedes Volkes. Aus diesem Grunde sollten wir den Termin Körperkultur, von dem wir uns so intensiv und lange befreien und ihn der Vergangenheit überlassen möchten, rehabilitieren, so wie es unsere Kollegen in Skandinavien tun, und ihm seine (für uns unabkämmliche) kulturelle Dimension zurückgeben. Wie wir wissen, befindet sich im Mittelpunkt unseres Fachs, der Körperkultur, der Mensch, das höchste Geheimnis, dem der Mensch selbst entgegentritt. Dieser Mensch nimmt körperliche Bewegung - Übung als wohltätige Nahrung, unumgänglich nicht nur für seinen Körper, sondern auch für seine Seele. Gerade darin, in diesem Entspringen der körperlichen Übung aus dem menschlichen Wesen liegt die Phänomenologie der Körperkultur. Der Mensch verspürt „Durst“ nach unterschiedlichen Formen der Befriedigung seiner kultureller Bedürfnisse. Sowie er das Bedürfnis nach einem guten Buch, nach lieblicher Musik, nach einem schönen Bild verspürt ... hat er auch das Bedürfnis, der körperlichen Übung im diätätischen und agonistischen Sinne all das hinzu zu fügen, was wir aufgezählt haben. Diese Erwartungen des Menschen, der nach geistlicher und körperlicher Nahrung dürstet, müssen befriedigt werden. Gedruckte und elektronische Medien sind eine gute Gelegenheit, um auf diese Bedürfnisse zu antworten. Diese Medien sind in jedem Moment zugänglich für alle Menschen, die immer weniger Freizeit haben. Dies ist eine Gelegenheit, sie „im Gehen“ zu informieren und sie dazu zu inspirieren, sich auch dieser Seite ihrer kultureller Bedürfnisse zuzuwenden - der Körperkultur.
\end{abstract}

Schlüsselwörter: DER MENSCH ALS KULTURWESEN / KÖRPERKULTUR / MEDIEN

Примљен: 01. 11.2017. Прихваћен: 15. 11.2017. 